\title{
Status of Vocational Education and Training for Korean Middle- aged Career Interrupted Women in Korea
}

\author{
Yun-Jeong Kim ${ }^{1}$, Soon-Hee Ryu ${ }^{2}$, and Sang-Jin Lee ${ }^{3 *}$ \\ ${ }^{I}$ Department of Health, Counseling and Welfare, Hanseo University, Professor, \\ Republic of Korea \\ ${ }^{2}$ Seosan Healthy Family, Multicultural Family Support Center, Center Director, \\ Republic of Korea \\ ${ }^{3}$ Chungcheongnam-doPublic Agency for Social Service, Team Manager, \\ Republic of Korea, \\ 1'twoyun21@hanmail.net, 2ajangee@hanmail.net, ${ }^{3}$ welfare-i@hanmail.net
}

\begin{abstract}
The purpose of this study was to understand the status of vocational education for careerbreaking women aged between 40 and 64. Lee, Yang, Song, and Kim (2020) used the data, which was investigated for the "lifetime vocational education and training plan for employment links over middle-aged." Thus, this study used the secondary data from a web survey method using questionnaires and a self-subjective survey which were conducted simultaneously in February 2020. Among the data, 328 women aged 40 to 64 who had a job before but are now jobless and have the desire to find a job, were analyzed. According to the survey of careerinterrupted women's participation in vocational education and training, only 21.6 percent of them have participated in vocational education and training. In terms of the number of vocational education participants over the past five years, $59.2 \%$ of the participants participated in the program, and 1.4\% participated in the program four times. As for the purpose of participation in vocational education, 're-employment' was the highest reason noted at $46.5 \%$, 'acquired certificates' was shown to be $21.1 \%$, and 'improvement job skill' was at 15.5\%. The institutions that received vocational education and training were $25.4 \%$ of' 'vocational education and training corporations', $23.9 \%$ of' 'public vocational training institutions', $18.3 \%$ of 'private academies', and 11.3\% of' 'women's workforce development centers' Second, the careers of women who participated in vocational education and training were often 'service/sales business'.
\end{abstract}

Keywords: Career interrupted women, Vocational education and training, Job seeking skills, Basic job competence

\section{Introduction}

It is observed that Korean women's economic participation rate has stagnated at around 50 percent over the past decade, ranking at the bottom of the OECD list. The average participation rate of women's economic activities in OECD countries was 62.3\% in 2012 and 64.0\% in 2017 [1]. In addition, according to the National Statistical Office's regional employment survey [3], the number of career-interrupted women increased by $15,000(0.8 \%)$ year-on-year to 1.847

Article history:

Received (December 21, 2020), Review Result (January 22, 2021), Accepted (February 26, 2021) 
million, and the proportion of career-interrupted women between the ages of 15 and 54 rose by $0.5 \%$ p to $20.5 \%$. In other words, the proportion of career-interrupted women is noted as being on the rise, amid the low participation rate of women in economic activities in OECD countries.

Fortunately, vocational training has been shown to help re-employment of women with a desire to go back into viable job markets, and has enhanced their job performance once hired on a job [2]. In 2019, 14,544 career-interrupted women participated in 745 vocational training courses through the Sail Center and the number of employed people through vocational training was 10,258 in 2018 [3]. Therefore, it is time for career-interrupted women to identify variables that affect their participation in vocational education and training, and to study ways to support vocational education and training. In this way, career-interrupted women who have a desire to seek a job can re-enter the labor market, even though the rate of participation in vocational education and training is low and decreasing.

The purpose of this study is to identify the determinants of participation in vocational education and training for career-interrupted women aged 40 to 64 living in Korea. First, it is important to grasp the status of vocational education and training of career-interrupted women in this country. Second, differences in participation in vocational education and training according to socio-economic characteristics and job characteristics before career breaks are identified.

\section{Method}

\subsection{Data collection procedure}

This study used the data of Lee, Yang, Song \& Kim [6], which is noted from the 'Lifelong Vocational Education and Training Plan for Employment Connections of middle-aged and older employment'. The Web survey method using the questionnaire and the self-subjective survey were conducted simultaneously for one month in February 2020. The collected data was used for a total of 1,224 analyses, excluding those that were poorly responded, those that were error-prone, and those that were unresponsive through the data cleaning process. Among the data, in this study, 328 women aged 40 to 64 who had a job but did not have one now, but who had a desire to have one, were analyzed.

\subsection{Measurement}

In the study, among the questions asked was: Whether or not to participate in vocational education and training whereby the participants were asked to answer yes or no to a single question, 'Have you participated in vocational education and training in the past 5 years?'. The level of economic retirement preparation was a 5-point Likert-type scale from "not at all" (1 point) to "very much" ( 5 point) for the two questions of "preparing pensions, savings and insurance for economically comfortable retirement" and "preparing for income activities after retirement." The analysis used an average of two questions.

Basic job competency was measured in 16 questions in eight areas by correcting and supplementing the standards in the 2013 National Competency Standards [7] and utilization package. As noted, this is a 5-point Likert-type scale from "not at all (1 point)" to "very much (5 points)". Likewise, the reliability of the scale is .950 .

Job-seeking skills was a measurement developed by Lee [5] based on prior research, with 20 questions, but nine reduced questions were used after an advisory meeting. It is a five-point recurve measure from "not at all" (1 point) to "very much" (5 point). In these terms, the reliability of the scale is .873 . The status of participation in vocational education and training 
was asked about the number of vocational education and training participants, the purpose of participating in vocational education and training, and the institutions participating in vocational education and training.

\subsection{Socio-demographic characteristics of career-interrupted women in Korea}

According to the social-demographic characteristics of career-interrupted women in the study, the percentage of people in their $40 \mathrm{~s}$ and $50 \mathrm{~s}$ is $50 \%$. This result is noted because quota sampling was used by age groups in the process of collecting research data. In this group, 51.8 percent of college graduates and 48.2 percent of college graduates or younger had similar rates. The majority of these cases are $75.9 \%$ married, with $88.4 \%$ of the residents mainly residing in cities (large and small cities). While the economic status is concentrated in the middle class and the lower class, the economic condition is low at 3.45 out of 5 , and the health condition is somewhat healthy at 3.36 .

\subsection{Statistical analysis}

Frequency analysis, cross-tab analysis using IBM SPSS24.0.

\section{Results}

\subsection{The status of participation in vocational education and training of career-interrupted women}

According to the survey of career-interrupted women's participation in vocational education and training, only 21.6 percent of them have participated in vocational education and training [Table 1].

Table 1. Participation in vocational education and training $(\mathrm{N}=328)$

\begin{tabular}{|c|c|c|}
\hline & $\mathrm{N}$ & $\%$ \\
\hline Yes & 71 & 21.6 \\
\hline No & 257 & 78.4 \\
\hline
\end{tabular}

In terms of the number of vocational education participants over the past five years, $59.2 \%$ of the participants participated in the program, and $1.4 \%$ participated in the program four times. As for the purpose of participation in vocational education, 're-employment' was the highest reason noted at $46.5 \%$, 'acquired certificates' was shown to be $21.1 \%$, and 'improvement job skill' was at $15.5 \%$. The institutions that received vocational education and training were $25.4 \%$ of' 'vocational education and training corporations', $23.9 \%$ of' 'public vocational training institutions', $18.3 \%$ of 'private academies', and $11.3 \%$ of 'women's workforce development centers' [Table 2]. 
Table 2. The status of participation in vocational education and training $(\mathrm{N}=71)$

\begin{tabular}{|c|c|c|c|}
\hline & & $\mathrm{N}$ & $\%$ \\
\hline \multirow{4}{*}{ Number } & 1 & 42 & 59.2 \\
\hline & 2 & 20 & 28.2 \\
\hline & 3 & 8 & 11.3 \\
\hline & 4 & 1 & 1.4 \\
\hline \multirow{5}{*}{ Purpose } & Start-up & 4 & 5.6 \\
\hline & Re-employment & 33 & 46.5 \\
\hline & Improved job skills & 11 & 15.5 \\
\hline & Acquired certificates & 15 & 21.1 \\
\hline & Others & 8 & 11.3 \\
\hline \multirow{6}{*}{ Institutions } & Private academy & 13 & 18.3 \\
\hline & $\begin{array}{l}\text { Vocational education and } \\
\text { training corporations }\end{array}$ & 18 & 25.4 \\
\hline & $\begin{array}{l}\text { Public vocational training } \\
\text { institutions }\end{array}$ & 17 & 23.9 \\
\hline & Welfare Center, Ward Office & 8 & 11.3 \\
\hline & $\begin{array}{l}\text { Women's workforce } \\
\text { development centers }\end{array}$ & 8 & 11.3 \\
\hline & Others & 7 & 9.8 \\
\hline
\end{tabular}

\subsection{Differences in participation in vocational education and training according to personal characteristics}

Looking at the differences in participation in vocational education and training based on the personal characteristics of career-interrupted women, only the differences in health condition and job type were shown to have been significant in this case. In other words, 56.3 percent of women who participated in vocational education and training were in good health, while 43.2 percent were in good health. Women who participated in vocational education and training were in better health conditions. In addition, $36.6 \%$ of women who participated in vocational education and training were engaged in the 'service/sales business', while $46.3 \%$ were 'other occupations' for women who did not participate. In other words, the job type of women who participated in vocational education and training were shown to be with more stable types of jobs. However, differences in career education and training participation in vocational training based on the age, educational background, marital status, residence, employment patterns and voluntary resignation of career interrupted women were not statistically significant [Table 3]. 
Table 3. Differences in Participation in Vocational Education and Training by Personal Characteristics $(\mathrm{N}=328)$

\begin{tabular}{|c|c|c|c|c|}
\hline & & \multicolumn{2}{|c|}{$\begin{array}{c}\text { Participation in vocational education and } \\
\text { training }\end{array}$} & \multirow{2}{*}{ chi-square } \\
\hline & & Yes & No & \\
\hline \multirow{3}{*}{ Health Condition } & Bad & $3(4.2 \%)$ & $42(16.3 \%)$ & \multirow{3}{*}{$8.057^{*}$} \\
\hline & Common & $28(39.4 \%)$ & $104(40.5 \%)$ & \\
\hline & Good & $40(56.3 \%)$ & $111(43.2 \%)$ & \\
\hline \multirow{4}{*}{ Job type } & Manager/Expert & $11(15.5 \%)$ & $36(14.0 \%)$ & \multirow{4}{*}{$14.018^{*}$} \\
\hline & Office worker & $16(22.5 \%)$ & $25(9.7 \%)$ & \\
\hline & Service/Sales worker & $26(36.6 \%)$ & $77(30.0 \%)$ & \\
\hline & \multirow[t]{2}{*}{ Others } & $18(25.4 \%)$ & $119(46.3 \%)$ & \\
\hline & & $71(100.0 \%)$ & $257(100.0 \%)$ & \\
\hline
\end{tabular}

\section{Conclusion}

The purpose of the study was to identify the determinants of participation in vocational education and training for Korean career-interrupted women aged 40 to 64 . The following is a summary of the main results. This study used the data of Lee, Yang, Song \& Kim [6], which is 'Lifelong Vocational Education and Training Plan for Employment Connections of middleaged and older employment'. The Web survey method using the questionnaire and the selfsubjective survey were conducted simultaneously for one month in February 2020. Among the data, in this study, 328 women aged 40 to 64 who had a job but did not have one now, but who had a desire to have one, were analyzed.

First, 21.6 percent of career-interrupted women had participated in vocational education and training, which was slightly higher than the 16 percent, this was slightly higher than $16 \%$ in the study by Go and Kim [7]. It was found that they received vocational education and training at 'Vocational education and training corporations' mainly for reemployment, with only 11.3 percent receiving training at the 'Women's Workforce Development Centers', one of the leading vocational education and training institutions for career-interrupted women. This shows that the 'Women's Workforce Development Center' has low recognition as a vocational education and training institution for women, and has low preference for education and training programs provided by the institution. For this reason, the identified 'strengthen promotion of vocational education and training programs' would have been the top priority among measures to support participation in vocational education and training among the participants to the program.

Second, the job before career breaks for women who participated in vocational education and training was often shown as in 'service/sales business'. However, among the vocational training programs operated by the National Women's Newly Work Center, the most frequently 
opened areas were 'management, office, finance, and insurance', followed by 'education, legal, social welfare, police, fire fighting and military' courses, and 'beauty, travel, lodging, security and cleaning jobs' [8]. In addition, the MOGEF [8] also expanded its high value-added jobs, including big data analysis marketing, pharmaceutical bio molecular diagnostics, pharmaceutical quality management, and training of HACCOP quality managers, from ' 46 in 2017 to 50 in ' 20 '. There seems to be a slight gap between what career women used to work for and what vocational education and training courses are currently open today.

\section{References}

[1] e-Nara indicators, "Female economically active population and participation rate," http://www.index.go.kr/potal/main/EachDtlPageDetail.do?idx_cd=1572, Jun 22, (2020)

[2] E. Y. Moon, M. Y. Bae, Y. S. Jo, and N. R. Choi, "Seoul metropolitan government's career disconnection prevention policy utilization survey and cooperation project promotion plan," Seoul-Focused on Familyfriendly Companies in Seoul's Small and Medium Enterprises, Seoul Women's Competency Development Center, (2019)

[3] Ministry of Gender Equality and Family, Ministry of Gender Equality and Family Policy Guidance for 2020

Sail Center Vocational Education Results,

http://www.mogef.go.kr/kor/skin/doc.html?fn=805c5aa0ce824bfcaac162611b80d19a.hwp\&r $\mathrm{s}=/$ rsfiles/202007, July 22, (2020)

[4] Ministry of Gender Equality and Family, Toward Equality in Everyday Life, http://blog.naver.com/mogefkorea/22197006920, July 22, (2020)

[5] Y. J. Lee, "Factors affecting the job search behavior of the career - interrupted women: Focusing on ChungCheongnam-Do," M.S. Department of Social Welfare, Gongju National University, Gongju City, (2019)

[6] S. J. Lee, J. S. Yang, K.W. Song, and Y. J. Kim, "Lifelong vocational education and training plan form" Connections Middle-aged and Older Employment, Korea Research Institute for Vocational Education and Training, (2020)

[7] NCS, https://www.ncs.go.kr/th03/TH0302List.do?dirSeq=121, April 2, (2020)

[8] H. Y. Go and B. E. Kim, "A study to construct a specialized program for the Seoul women's development center," Seoul Women's Competency Development Center, Korea Professional Qualification Association, (2020) 